
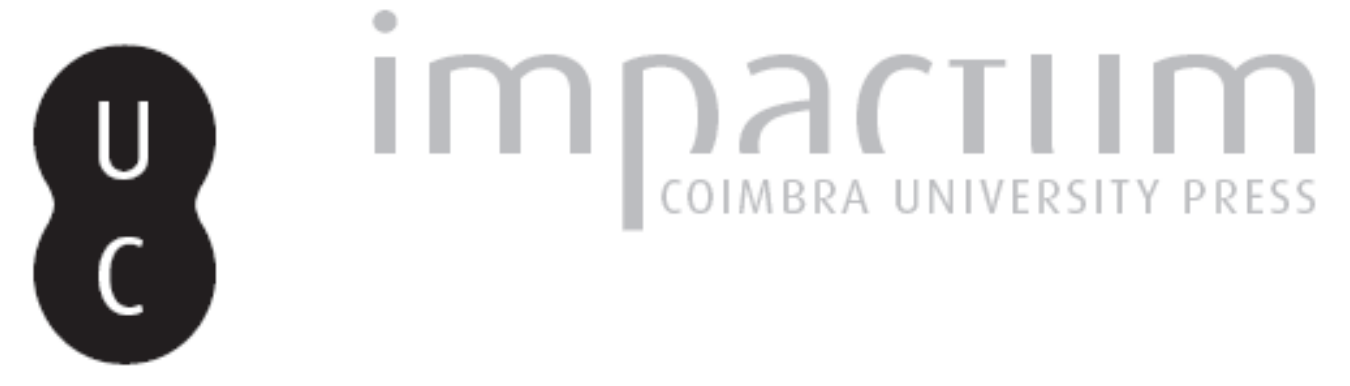

\title{
A evolução das guerras coloniais na perspectiva dos relatórios de informação
}

\section{Autor(es): $\quad$ Mateus, Dalila Cabrita}

Publicado por: Imprensa da Universidade de Coimbra

URL persistente:

URl:http://hdl.handle.net/10316.2/45002

DOI:

DOI:https://doi.org/10.14195/0870-4147_38_7

Accessed : $\quad$ 26-Apr-2023 01:19:15

A navegação consulta e descarregamento dos títulos inseridos nas Bibliotecas Digitais UC Digitalis, UC Pombalina e UC Impactum, pressupõem a aceitação plena e sem reservas dos Termos e Condições de Uso destas Bibliotecas Digitais, disponíveis em https://digitalis.uc.pt/pt-pt/termos.

Conforme exposto nos referidos Termos e Condições de Uso, o descarregamento de títulos de acesso restrito requer uma licença válida de autorização devendo o utilizador aceder ao(s) documento(s) a partir de um endereço de IP da instituição detentora da supramencionada licença.

Ao utilizador é apenas permitido o descarregamento para uso pessoal, pelo que o emprego do(s) título(s) descarregado(s) para outro fim, designadamente comercial, carece de autorização do respetivo autor ou editor da obra.

Na medida em que todas as obras da UC Digitalis se encontram protegidas pelo Código do Direito de Autor e Direitos Conexos e demais legislação aplicável, toda a cópia, parcial ou total, deste documento, nos casos em que é legalmente admitida, deverá conter ou fazer-se acompanhar por este aviso.

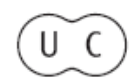



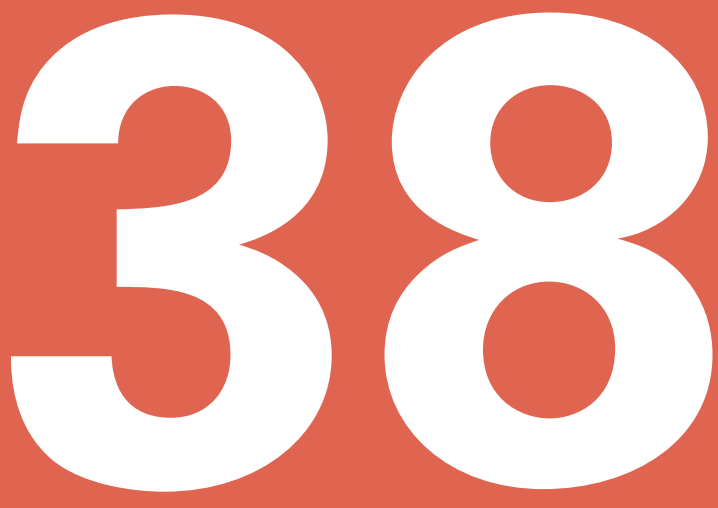

\section{Revista Portuguesa de História}

Faculdade de Letras da Universidade de Coimbra Instituto de História Económica e Social

Coimbra 08 


\section{A evolução das guerras coloniais na perspectiva dos relatórios de informação}

Antes do 25 de Abril, o Presidente do Conselho de Ministros (Oliveira Salazar primeiro, Marcelo Caetano depois) recebia, praticamente todos os dias, informações sobre a evolução das guerras que se travavam em África. Boa parte dessa informação estratégica vinha da PIDE/DGS, organização que, na prática, a centralizava ao nível do Governo, muito embora tal missão nunca lhe tivesse sido atribuída por lei.

Escusado será dizer que as informações recolhidas oferecem todas as garantias de segurança, tanto mais que são classificadas no que respeita à credibilidade da fonte, assim como à verosimilhança da notícia. De resto, seria pouco promissor o futuro da PIDE/DGS como serviço de inteligência, se se provasse que enviava ao Governo e aos Estados-Maiores das Forças Armadas informações que depois se revelavam falsas.

Façamos, então, uma síntese da evolução das guerras coloniais em Angola, em Moçambique e na Guiné-Bissau, principalmente com base nos relatórios elaborados pelos analistas daquela polícia. Principalmente, mas não só. Com efeito, sobretudo no caso da Guiné, sendo aqueles relatórios mais fracos, socorremo-nos, também, de outras fontes. 


\section{A guerra em Angola}

Em Angola, dois acontecimentos assinalam o início da guerra colonial: o 4 de Fevereiro e o 15 de Março.

Em 4 de Fevereiro, umas centenas de africanos, armados de catanas, assaltam a Cadeia de S. Paulo, a Casa de Reclusão Militar e a Esquadra Móvel da PSP. A acção visaria dois objectivos: em primeiro lugar, libertar os presos políticos; em segundo lugar e aproveitando a presença em Luanda de muitos jornalistas estrangeiros (atraídos pelo facto de se dizer que o navio Sta. Maria, tomado pelo capitão Henrique Galvão, rumava a Angola), chamar a atenção para a opressão colonial. Os assaltantes, que sofrem baixas ligeiras, matam 7 polícias e apoderam-se de algumas armas.

Aparentemente entusiasmados com o êxito da iniciativa, a 11 de Fevereiro, repetem o ataque. Só que, desta vez, a polícia está prevenida. Muitos são logo mortos, os outros presos. E não raro também mortos.

Pertenciam a vários quadrantes políticos. Embora a maioria dos participantes fosse da família MPLA, que aliás reivindicou a paternidade da acção. Num documento interceptado pela PIDE e enviado a Salazar, uma "entidade estrangeira com responsabilidades políticas" envia ao governo do seu país uma informação em que se afirma:

"Os tumultos de Luanda, em Fevereiro de 1961, que em conjunto com o caso do 'Santa Maria' marcam o início da insurreição angolana, foram organizados por elementos do MPLA ou próximos do MPLA". Tendo, ainda, acrescentado que Holden Roberto, da UPA, tinha "procurado tirar vantagem disso e atribuir-se o 'mérito' por meio de múltiplas conferências de imprensa e declarações na rádio"”.

Pouco tempo depois, a 15 de Março, verificam-se acções de terrorismo na região dos Dembos, no Norte de Angola. A polícia tomara conhecimento dos preparativos para tais acções, desta vez promovidas em exclusivo pela União das Populações de Angola (UPA).

Em fins de 1960, um seu colaborador envia de Leopoldville uma carta a anunciar "uma grande revolta".

Já em Janeiro de 1961, em Nóqui, o responsável da PIDE informa que a actividade da UPA se intensificara junto à fronteira, sublinhando que se estava a preparar um grande plano de terror ${ }^{3}$.

$1 \mathrm{AOS} / \mathrm{CI} / \mathrm{UL}-50$, pasta 2, f. 505.

2 IAN/TT, Arquivos da PIDE, Processo 11.12.A, UPA, f. 265.

3 IAN/TT, Arquivos da PIDE, Delegação de Angola, D. Inf., $1^{\circ}$ Processo 11.12.B, UPA, fls. 467ss. 
E na própria véspera, o posto da PIDE em S. Salvador difunde uma informação em que se afirma que, no dia seguinte, se ia verificar um ataque da UPA ${ }^{4}$.

Facto é que as informações policiais não foram levadas a sério pelos responsáveis políticos e militares. De resto, naquela altura, os efectivos militares na colónia não iam além dos 6.500 homens, sendo 1.500 portugueses e 5.000 africanos.

A angolana Ana Inglês conta que, no dia 16 de Março, depois dos ataques a Quitexe, Balongongo e Aldeia Viçosa, "ao longo do caminho vimos um enorme morticínio de pessoas brancas e pretas, sem braços, sem pernas, sem olhos".

Nos Arquivos da PIDE, encontram-se umas dezenas de fotografias, bem expressivas do horror indescritível associado aos massacres da UPA. Numa dessas fotografias, vêem-se dezenas de corpos de bebés, brancos e mestiços. Noutra, estão corpos de mulheres brancas, despidas da cintura para baixo e com os membros cortados ${ }^{6}$.

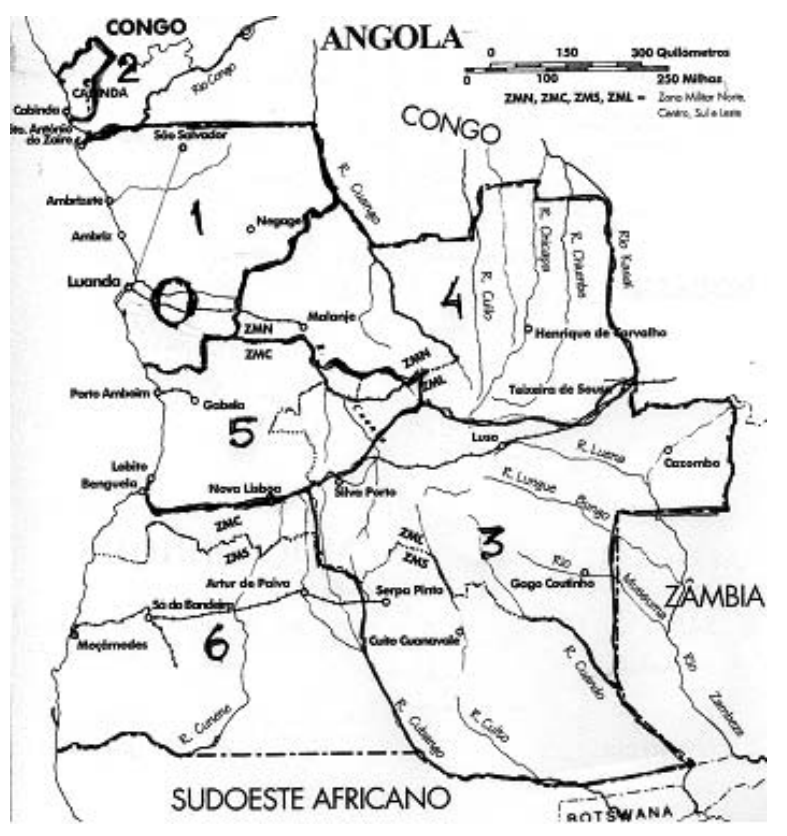

${ }^{4}$ IAN/TT, Arquivos da PIDE, Delegação de Angola, D. Inf., $1^{\circ}$ Processo 11.12.B, UPA, f.499.

5 Ana Inglês, entrevista, in Dalila Cabrita Mateus, Memórias do Colonialismo e da Guerra, ASA, Porto, 2006, p. 92.

6 IAN/TT, Arquivos da PIDE, Processo 16.10.A, Terrorismo. 
Ao terror negro vai contrapor-se o terror branco. O soldado Etelvino anota: "O maior prazer de certos brancos é matar pretos. Quando chegavam a Luanda camionetas cheias de pretos presos, os brancos civis abatiam-nos a tiro, como se fossem cães"'.

Na então Metrópole, os jornais publicitaram as barbaridades cometidas pela UPA, que serviram ao regime para mobilizar a opinião pública para a guerra. E Salazar, que passara a ocupar a pasta da Defesa depois de derrotada a tentativa de golpe de Botelho Moniz, ordena o envio rápido e em força de tropas para Angola.

Começa, pois, a guerra. Já em princípios de 1964, nas regiões de Ambriz, Ambrizete, Muserra e Quingombe, a polícia considera que o inimigo dispunha de "excelente informação" do que se passava nessas regiões. E revelava, ainda, "uma razoável preparação técnica e táctica nos aspectos operacionais de manejo das armas utilizadas, dada a precisão de tiro com que atingiu objectivos visados e bem definidos".

O distrito de Malange estaria, então, ameaçado a Norte pela UPA e a Sul pela UNITA. Contudo, o único movimento que preocupava realmente a polícia era o MPLA, que tinha a intenção de estabelecer uma ligação entre o Moxico e o Cuando Cubango (III Região Militar) e os distritos de Luanda, Cuanza Norte, Uige e Zaire (I Região Militar), através de Malange?.

Em Abril de 1966, o MPLA materializa uma "mudança de esforço no Leste, transferindo do Congo Brazza para a Zâmbia elevados efectivos e infiltrando cinco destacamentos em Angola". A UNITA, por seu lado, desencadeia as primeiras acções no Leste de Angola, junto à fronteira ${ }^{10}$.

Em finais de 1966, face às informações recolhidas, concluía-se que o MPLA mantinha o seu dispositivo em direcção a Cabinda e prosseguia nas tentativas de se infiltrar na região Norte de Angola. Quanto ao Leste, afirmava-se que a dispersão a que as grandes distâncias obrigavam eram um factor facilitador da acção repressiva. Quanto à UPA, afirma-se que a informação recebida traduzia o propósito de reactivação em todas as frentes ${ }^{11}$.

Em 1967, o MPLA "expande-se no Norte, em zonas de influência da FNLA, reforça os cinco destacamentos e amplia a sua acção no Leste”. Admite-se que o movimento prepare acções de grande envergadura, visando

\footnotetext{
7 Etelvino da Silva Batista, Diário de Guerra, Três Sinais Editores, Lisboa, 2000. p. 19.

8 IAN/TT, Arquivos da PIDE, Processo 16.10.A, Terrorismo, fls. 230 ss.

9 IAN/TT, Arquivos da PIDE, Subdelegação de Malange, MPLA, pasta 1, fls. 300 ss.

${ }^{10}$ IAN/TT, Arquivos da PIDE, Processo 6573 CI(2), UNITA, volume 1, fls. 392 e 403.

${ }^{11}$ IAN/TT, Arquivos da PIDE, Processo 110.00.30. MPLA, pasta 7, fls. 62 ss.
} 
em especial o Saliente de Cazombo e outros pontos da Zona de Intervenção Leste, designadamente os centros mais populosos ${ }^{12}$.

Já em 1969, no Norte, o MPLA estava isolado desde 1967, tendo uma reduzida actividade. Mas, no Leste, consolidara a sua posição e ameaçava Nova Lisboa, ultrapassando e envolvendo a UNITA. No Luso, a situação alterara-se com a utilização de minas, anticarro e antipessoal. Os guerrilheiros teriam efectuado emboscadas e flagelações a destacamentos militares e povoações, utilizando metralhadoras e granadas de mão. Agora no Uige, assinala-se a passagem de grupos de guerrilheiros, que se julga serem da UPA e que atacam aldeias e fazendas, fazendo emboscadas com fogo de morteiro e flagelamentos à distância ${ }^{13}$.

Em 1970, em Cabinda, o MPLA estava numa situação desesperada. Contudo, no Leste continuava a desenvolver todos os esforços no sentido de materializar a penetrante que passará pelos rios Cuango, Cuapo e Cassique, no distrito do Bié". A UNITA, por seu lado, estaria a tentar refugiar-se a sul do distrito de Malange, a partir da qual tencionava desencadear acções em áreas do distrito do Bié. Finalmente, a UPA manifestava-se bastante activa "nas áreas de Santar, Alto Chicapa e Luma-Cassai" "14.

A polícia refere o facto de uma série de dirigentes do MPLA ter sido morta, o que não podia deixar de afectar o desenvolvimento da acção.

Em 1972, a média mensal das acções dos guerrilheiros era de 153. O MPLA efectuara 72, a maioria na região Leste (III Região Militar) ${ }^{15}$.

Em finais de 1972, a polícia salienta haver sinais de enorme perturbação nas fileiras do MPLA. O analista da PIDE/DGS apontava as seguintes causas para os problemas do movimento: primeira, a inércia dos dirigentes e dos quadros militares, que se encontravam no exterior desligados dos guerrilheiros que travavam a luta no país; segunda, a persistência da contestação à direcção político-militar; terceira, a fraca expressão do trabalho dos organizadores-mobilizadores na IV e V Regiões Militares (respectivamente, Lunda e Malange e Bié. Huambo, Benguela e Cuanza Sul); quarta, a quase inactividade da II Região Militar (Cabinda); e última, o isolamento da I Região Militar (Luanda, Cuanza Norte, Uige e Zaire) ${ }^{16}$.

${ }^{12}$ IAN/TT, Arquivos da PIDE, Processo 110.00.30. MPLA, pasta 9, fls. 9 ss.

${ }^{13}$ IAN/TT, Arquivos da PIDE, Processo 11.26.K, Contra-Subversão - Carmona, fls. $514 / 515$.

${ }^{14}$ IAN/TT, Arquivos da PIDE, Processo 2126/59 SR, UPA, fls. 1038 ss.

${ }^{15}$ IAN/TT, Arquivos da PIDE, Processo 11.03.B, Comando-chefe das Forças Armadas de Angola, pasta 1, fls. 1/47.

${ }^{16}$ IAN/TT, Arquivos da PIDE, Processo 110.00.30, MPLA, pasta 20, fls. 19/81. 
No MPLA, historicamente, coexistiram dois movimentos: um, o oficial, cujos dirigentes se encontravam no exterior, periodicamente atravessado por dissenções e, na prática, reduzido à guerrilha da chamada III Região Militar; o outro, com umas centenas de guerrilheiros às portas da capital, a chamada I Região Militar, apoiada pelas redes clandestinas que se formavam em Luanda e que, devido à repressão, iam alimentando prisões e campos de concentração. O único contacto entre estes dois movimentos eram as emissões do MPLA oficial, na Rádio Brazzaville. Depois do 25 de Abril, o "outro" movimento, reforçado organicamente, resistiu às investidas da FNLA e preparou a recepção apoteótica a Agostinho Neto. Os seus membros sofrem, entretanto, uma profunda desilusão: nem o MPLA oficial nem o seu Presidente correspondiam ao mito que tinham criado. O choque entre os dois movimentos levará ao 27 de Maio de 1977 e à morte dos principais dirigentes e de milhares de activistas e simpatizantes deste MPLA não oficial, executados sumariamente. Eram acusados de ter planeado, ao longo de três anos, o açambarcamento da revolução angolana e, ainda, de serem elitistas, incapazes de ultrapassar preconceitos pequeno-burgueses ${ }^{17}$. Em obra recente, consagrada a Agostinho Neto, escreve-se: "Em consequência do Movimento de Rectificação que se seguiu, o número de militantes do MPLA baixou de 110 mil para 32 mil. E esta é, ainda hoje, uma das páginas mais sombrias da história de Angola independente"18.

Voltemos a 1972. Na área da Zâmbia que se estendia ao longo do rio Zambeze, a perturbação era de tal ordem que havia guerrilheiros a vender armas a cidadãos zambianos. Nota-se um refluxo da actividade do MPLA, acompanhado pelo não acatamento das ordens do Comité de Coordenação Político-Militar e do Comité Director, órgãos de direcção no plano militar e político-militar ${ }^{19}$.

Em 1973, segundo a PIDE, o número de guerrilheiros dos três movimentos seria o seguinte: MPLA com 3.000 homens; FNLA com 2.000; e UNITA com $300^{20}$. Como termo de comparação, assinale-se que as tropas portuguesas em Angola chegaram a totalizar 70.000 homens, dispondo de 94 aviões (38 armados), 45 helicópteros, 8 navios e 16 lanchas de embarque ${ }^{21}$.

${ }^{17}$ David Birmingham, Portugal e África, Veja, s/1, 2003, p. 186.

${ }^{18}$ Moutinho Pereira, «Um Homem nos Alicerces do Mundo», in AA.VV., Agostinho Neto, Uma Vida sem Tréguas (1922/1979)”, ed. particular, Lisboa/Luanda, 2005.

${ }^{19}$ IAN/TT, Arquivos da PIDE, Processo 110.00.30. MPLA, pasta 23, fls. 87 ss.

${ }^{20}$ IAN/TT, Arquivos da PIDE, Processo 110.00.30. MPLA, pasta 25, fls. 100 ss..

${ }^{21}$ Aniceto Afonso e Carlos Matos Rodrigues, Guerra Colonial, ed. Notícias, Lisboa, 2000, p.15. 
Nos primeiros dias de Maio de 1973, entram em Angola 30 elementos do Batalhão $\mathrm{n}^{\circ} 2$ do ELNA, braço armado da UPA/FNLA. E em meados do mês entram mais dois grupos de 50 elementos, do mesmo batalhão. A polícia refere $o$ empenho deste movimento na captura de um militar português, que seria depois usado para fins de propaganda, como demonstração da actividade do ELNA. Acrescenta que a FNLA tinha o propósito de fixar, com carácter permanente, efectivos deste Batalhão ${ }^{0} 2$ nas áreas de Santa Cruz ou Quibele, no Norte ${ }^{22}$. Já em finais do ano, o ELNA disporia de grande quantidade de material de guerra, mas estaria em dificuldades por falta de gente. Por isso mesmo, estaria a recrutar nas áreas de Dilolo, Kapanga e Sandoa, com o apoio das autoridades do Zaire ${ }^{23}$.

Em meados de 1973, a PIDE/DGS assinalava várias operações realizadas pelos movimentos independentistas.

O MPLA desenvolvera as seguintes acções: em Cabinda (emboscadas esporádicas e implantação de minas na fronteira), em Luanda (sabotagem económica e reacções fracas à penetração das tropas portuguesas), no Cuanza Norte (sabotagem económica, saque de estabelecimentos e ataques aos Caminhos de Ferro), no Moxico (implantação de minas, ataques a povoações e aquartelamentos na área de fronteira com a Zâmbia) e no C. Cubango (acções contra populações africanas, ataques a quartéis e implantação de minas).

Quanto à UPA/FNLA realizara: no Zaire (emboscadas a colunas e ataques a quartéis junto à fronteira), no Uige (emboscadas a viaturas civis, flagelação de fazendas, acções contra trabalhadores africanos, saque de acampamentos e aldeias, destruição de culturas), no distrito de Luanda (flagelação a fazendas, emboscadas a colunas e acções contra aldeamentos), no Cuanza Norte (emboscadas a viaturas civis, flagelações a fazendas, acções contra trabalhadores africanos, saque a acampamentos e aldeias, destruição de colheitas) e no Moxico (emboscadas e flagelações na área do Luso) ${ }^{24}$.

A UNITA, neste ano, não dá sinal de si. No entanto, em princípios de 1974, aproveitando as circunstâncias favoráveis resultantes dos problemas internos do MPLA e da conjuntura que se oferecia à guerrilha no Leste do país, desencadeia uma série de acções, que pretendiam mostrar "à opinião pública que era o movimento mais válido" e totalmente instalado em Angola, "reforçando os pedidos de reconhecimento e apoio externo" 25 .

\footnotetext{
${ }^{22}$ IAN/TT, Arquivos da PIDE, Processo2126/59 SR, UPA, volume 4, fls. 114 ss.

${ }^{23}$ IAN/TT, Arquivos da PIDE, Processo 11.25.C/25, D. Inf. / ${ }^{\mathrm{a}}, F N L A$, fls. 4 ss.

${ }^{24}$ IAN/TT, Arquivos da PIDE, Processo 110.00.30, MPLA, pasta 25, fls. 100 ss.

${ }^{25}$ IAN/TT, Arquivos da PIDE, Processo 6573 SC/CI, UNITA, volume 5, fls. 240 ss.
} 
Em princípios de 1974, o MPLA estaria a passar por uma "crise de dissidências", que teria "as suas causas longínquas em contradições internas rácico-étnico-políticas", que se tinham agravado devido ao fracasso da manobra de expansão para Leste, assim como pela incapacidade de reabastecer e reactivar a I Região Militar, que continuava a resistir às portas da capital, embora quase sem armas e há anos sem qualquer contacto com a Direcção do MPLA ${ }^{26}$.

O MPLA, até então o movimento mais forte, estava dividido, psicologicamente abalado e, por isso, enfraquecido. E os outros movimentos não tinham a força necessária para constituir sérias ameaças. A guerra baixou de intensidade. Ainda assim, em finais de Março de 1974, a PIDE/DGS assinalava 123 acções, sendo 59 da FNLA, 43 do MPLA (25 no Leste) e 21 da UNITA ${ }^{27}$.

Aparentemente, a guerra colonial em Angola estava quase ganha pelas tropas portuguesas. Só que, este tipo de guerras não se ganha nos campos de batalha, mas na consciência e no coração dos homens. Dificilmente se poderia clamar vitória quando os independentistas continuavam a dispor de milhares de homens armados e treinados (fora e dentro do território em disputa e mesmo às portas da capital), quando possuíam equipamentos militares poderosos e sofisticados (por vezes mesmo mais poderosos que os das forças armadas portuguesas), quando não lhes faltavam apoios externos. E sobretudo quando largas camadas populares, nos campos e até nas cidades, estavam ganhas para a luta pela independência.

$\mathrm{Na}$ cidade de Luanda, por exemplo, de há muito que os africanos tinham ultrapassado a fase panfletária, pelo que lhes bastava ouvir a rádio para formarem redes clandestinas, que alimentavam com abastecimentos e com gente a I Região Militar do MPLA, que, apesar de todas as investidas das tropas, da polícia e dos guerrilheiros do ELNA, continuava a existir, mesmo que com poucas armas e praticamente sem munições. O principal analista da PIDE/DGS em Angola admitia mesmo que, no dia em que os independentistas conseguissem fazer chegar apoio logístico a estes guerrilheiros, a situação político-militar na capital angolana e noutras cidades sofreria um agravamento, pois as organizações clandestinas do sector urbano, dinamizadas com homens e armamento, começariam as sortidas sobre a cidade.

${ }^{26}$ IAN/TT, Arquivos da PIDE, Relatórios Imediatos: MPLA, pasta 1, fls. 33 ss.

${ }^{27}$ IAN/TT, Arquivos da PIDE, Processo 11.03.B, Comando-chefe das Forças Armadas de Angola, pasta 4, fls. 191/231. 


\section{A guerra em Moçambique}

Em 25 de Setembro de 1964, com apenas 250 guerrilheiros treinados, a Frente de Libertação de Moçambique inicia a luta armada, com um ataque à base portuguesa de Chai, no Norte de Moçambique. Simultaneamente emitia uma proclamação e um apelo às armas.

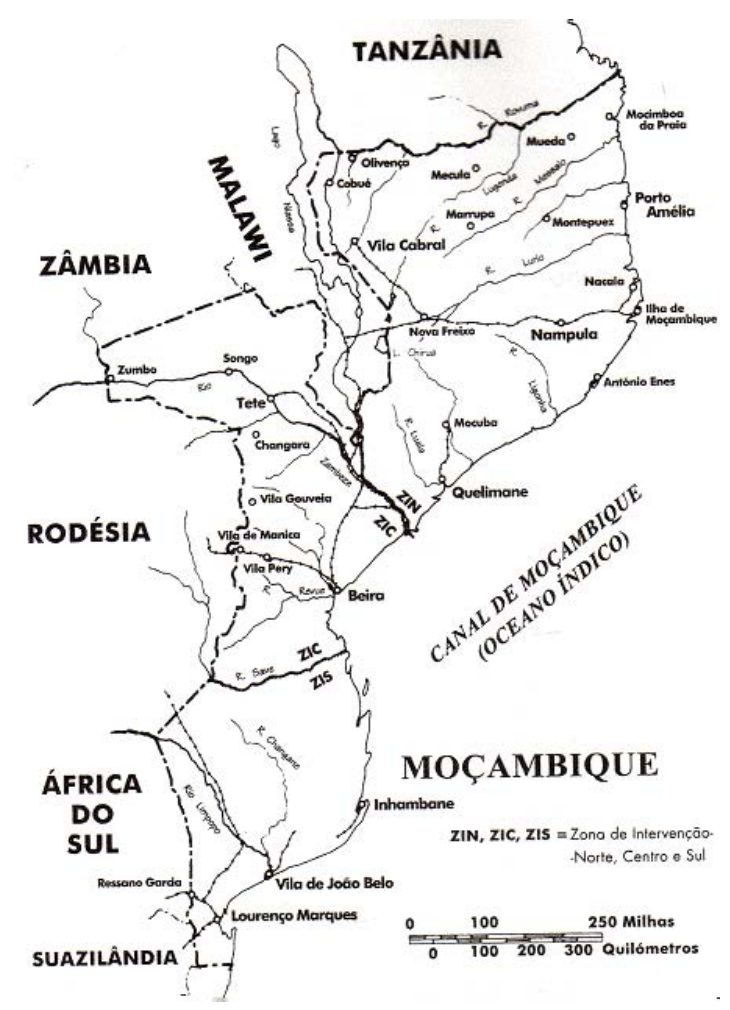

Pouco depois, a FRELIMO sofre um severo golpe. Com efeito, em Dezembro de 1964, é desmantelada a IV Região Militar da FRELIMO, que abarcava os distritos de Lourenço Marques, Gaza e Inhambane. São detidos todos os membros da direcção: Matias Mboa (comandante), Joel Maduna Chinana (comissário político), Lameque Michangula (adjunto do comandante) e outros. São, também, detidos numerosos intelectuais, membros das células de Lourenço Marques: José Craveirinha, Rui Nogar, Luís Bernardo Honwana, Malangatana Valente, Domingos Arouca e Ebenizário Gwambe, um sociólogo que será morto com torturas. São ainda presos muitas dezenas de activistas. A FRELIMO deixa praticamente de existir em Lourenço Marques. 
Em 1966, num relatório sobre a situação militar em Cabo Delgado, a PIDE escreve: "Para evitar as investidas do inimigo lançou-se mão de todos os meios ao nosso alcance. Não se pode evitar a fuga de população maconde (mais ou menos 55 mil) para o campo adverso. No concelho de Montepuez assiste-se a uma fase activa de propaganda do inimigo". Este teria aparecido "mais forte em número e material bélico, obrigando por isso a um maior dispêndio dos nossos objectivos armados, que nunca mais tiveram o controlo absoluto das áreas dos concelhos macondes, Mocimboa da Praia, Macomia e parte da circunscrição de Palma, onde só as sedes se mantêm efectivamente sob a nossa jurisdição" 28 .

Neste mesmo ano, a polícia afirma terem sido destruídas várias bases em Cabo Delgado, designadamente a base Limpopo. Os guerrilheiros teriam fugido, deixando no local diverso material de guerra (granadas, cunhetes e munições), assim como "documentos importantíssimos, quase na totalidade manuscritos num português correcto" 29 .

Em princípios de 1968, mais de 300 guerrilheiros atacam os quartéis de Nangololo, Dioca e Nambude ${ }^{30}$. E a polícia obtém "de fonte delicada, que requer protecção através da classificação máxima de segurança” (eufemismo que significa que a fonte é, apenas e tão só, um elemento da direcção ou trabalhando com a direcção da FRELIMO) um relatório do Secretário do Departamento de Defesa, Samora Moisés Machel, ao Comité Central da FRELIMO, reunido em Nachingwea, de 23 a 29 de Agosto, um mês depois da realização do Congresso da Frente. Face a este relatório, a PIDE conclui: "A situação militar no Niassa é má. O inimigo ocupa postos estratégicos da região"ß1.

Sebastião Mabote, dirigente responsável pelas operações da FRELIMO, visita as bases de Catur e Chalé. E na base Gungunhana confidência ir ausentar-se do Niassa por um período longo, no cumprimento de uma missão. É hoje possível adivinhar a missão de que fora incumbido: a abertura de uma nova frente, em Tete.

Em Março de 1969, José Matavele, secretário nacional do Departamento de Organização da FRELIMO, sobrevoa, num helicóptero da Tanzânia, parte do distrito do Niassa, lançando alimentos para os guerrilheiros da base central e da base subprovincial de Msumbigo. Comentando o facto, a PIDE sublinha que a FRELIMO continuava a debater-se com o problema da fome dos guerrilheiros,

\footnotetext{
${ }^{28}$ IAN/TT, Arquivos da PIDE, Processo 2737/64 SR, Chibuane Ali Namuanga, fls. 580 ss.

${ }^{29}$ IAN/TT, Arquivos da PIDE, Processo 2693/63 SR, Làzaro Cavandame e outros, fls. 60/61.

${ }^{30}$ IAN/TT, Arquivos da PIDE, Processo 2693/63 SR, Làzaro Cavandame e outros, fls 51/52.

${ }^{31}$ IAN/TT, Arquivos da PIDE, Processo 2826/62 SR, FRELIMO, $4^{\circ}$ volume, fls. 416 ss.
} 
mas mostrava ter um perfeito conhecimento do seu dispositivo militar no interior de Moçambique. Movimentava-se de helicóptero por zonas consideradas fiscalizadas e dispunha de meios eficientes para acudir aos seus combatentes em locais de maior acuidade ${ }^{32}$. A PIDE reconhecia que as autoridades portuguesas tinham perdido o controlo de parte das populações africanas e que existia uma ocupação efectiva de território por parte da FRELIMO $^{33}$.

Em meados de 1970, para fazer face à ofensiva da FRELIMO em Cabo Delgado, o general Kaúlza de Arriaga mobilizou mais de 8 mil homens e enormes meios materiais para uma operação de cerco e batida, que ficou conhecida por "Operação Nó Gordio". Conhecem-se os resultados. A base central "Moçambique" foi encontrada. Mas estava abandonada há meses. E abandonadas tinham sido, também, outras bases operacionais e logísticas. A FRELIMO, apesar do "esforço gigantesco" das tropas portuguesas, conseguiu "desenvolver a sua manobra de avanço para sul do distrito", desencadeando acções em áreas onde ainda não se tinham registado. A desorganização inicial causada pela “Operação Nó Górdio" acabou por ser ultrapassada. E os guerrilheiros, tendo recebido reforços humanos, implantaram novas bases não distantes dos locais onde as anteriores se situavam, apetrechando-as com novo material infiltrado. A PIDE sublinha que o moral dos guerrilheiros macondes era elevado, sendo raríssimos os casos de deserção.

Já no Niassa, nunca a situação teria sido tão favorável para as tropas portuguesas. Aqui, o moral dos guerrilheiros seria muito fraco, registando-se dissidências e deserções.

Quanto ao distrito de Tete, no período de princípios de Agosto de 1970 a finais de Janeiro de 1971, tinham-se registado 221 acções dos guerrilheiros, que provocaram 28 mortos e 173 feridos. A polícia afirma que "a actividade subversiva no distrito de Tete tem registado um aumento progressivo a partir de meados de 1970, não só no campo militar, mas também no domínio e pressão exercida sobre as populações "34. E esclarecia que a situação, grave até Março de 1971, se tornara gravíssima em Agosto desse ano, altura em que se atingira "o último grau da evolução", com a expansão para as áreas do sul do

${ }^{32}$ IAN/TT, Arquivo da PIDE, Processo SR 2737/64, Chibuane Ali Namuanga, fls 77 ss.

${ }^{33}$ IAN/TT, Arquivo da PIDE, Processo SC-CI(2)- DSI, Documentação referente a Moçambique, pasta 10 , fls $1 / 6$.

${ }^{34}$ IAN/TT, Arquivo da PIDE, Processo SC - CI(2) - DSI, Documentação referente a Moçambique, pasta 8 , fls $44 / 60$. 
distrito e pela iminência da passagem para os distritos de Vila Pery, da Beira e da Zambézia ${ }^{35}$.

Em princípios de 1971, Ian Smith, acompanhado por chefes dos serviços de informação militares e por um intérprete, visita Moçambique para conversações com o general Kaulza de Arriaga, então colocado no quartel general de Nampula. O inspector Joaquim Piçarra Sabino da PIDE/DGS confia ao seu colega do CIO que, segundo fontes dos seus serviços, a FRELIMO já estava estacionada ao Sul do Zambeze e, em princípios de 1972, começaria a avançar para a província de Manica e Sofala ${ }^{36}$. E oficiais rodesianos de ligação à Zona Operacional de Tete relatam, de forma pouco favorável, o facto de os soldados portugueses terem reduzido interesse na guerra, parecendo sobretudo preocupados com as atracções do clube nocturno local, o Maxim's. Dizem que a PIDE/DGS estava perfeitamente consciente da generalizada falta de moral nas fileiras dos soldados, mas que nada podia fazer ${ }^{37}$.

Jacinto da Cruz, que prestou serviço em Moçambique, confirma este estado de espírito dos soldados, ao afirmar: "Na minha companhia, nenhum soldado estava interessado ou em estar em África ou em fazer a guerra (...) Costumavam dizer: 'África é prós pretos, que estamos nós aqui a fazer?'",38. Por outro lado, antigos milicianos confessam acções como "não atacar para não ser atacado, sabotar operações, cooperar com os guerrilheiros "39.

Em princípios de Maio de 1972, o responsável da subdelegação da PIDE/DGS na cidade da Beira desloca-se a Nampula, onde se avista com Kaulza de Arriaga. Com base em informações recolhidas junto das brigadas da polícia, denuncia atitudes incorrectas dos militares para com as populações africanas, como detenções e perseguições, assaltos e agressões, destruição de palhotas e de machambas. Fala da indisciplina reinante e da falta de brio e aprumo, passando por "estados frequentes de embriaguez", "cenas de pancadaria e insultos", "desrespeito grave nas relações e vivências entre inferiores e superiores",

${ }^{35}$ IAN/TT, Arquivo da PIDE, Processo SC - CI(2) GU, Pastas de Moçambique, caixa 12, fls. $2 / 69$.

${ }^{36}$ H. Ellert, THE RHODESIAN FRONT-WAR (Counter-insurgency and guerrilla warfare - 1962/1980), Mambo Press, Gweru, 1993, pág. 86.

${ }^{37} \mathrm{H}$. Ellert, THE RHODESIAN FRONT-WAR (Counter-insurgency and guerrilla warfare - 1962/1980), Mambo Press, Gweru, 1993, pág. 90 e SD CI(2) GU, Pastas de Moçambique, caixa 11 , fls. $1 / 3$.

38 Jacinto da Cruz, ex-soldado de infantaria em Moçambique, in Daniel Alexandre Seabra Lopes, Ex-Combatentes da Guerra Colonial: Experiências e Identidades, dissertação de mestrado em Antropologia, ISCTE, 1998, pp. 147/148.

${ }^{39}$ Daniel Alexandre Seabra Lopes, Ex-Combatentes da Guerra Colonial: Experiências e Identidades, p. 157. 
"uso e abuso de armas de fogo em tiroteios desnecessários". E refere, ainda, a "falta de coordenação e de planificação dos esforços de defesa na região", assim como a falta de iniciativa na reacção às acções dos guerrilheiros ${ }^{40}$.

De resto, a PIDE/DGS duvidava seriamente das capacidades militares de Kaulza de Arriaga, considerando-o um general "ávido de glória e propaganda", a tentar inculcar no espírito dos que o rodeavam "quiméricos êxitos" e fazer crer numa "vitória estrondosa", que só não seria retumbante "por deficiência de determinados departamentos governamentais" "41. A polícia considera ineficaz a táctica usada em Cabo Delgado, dando um exemplo: aviões, helicópteros, material bélico vário e uma companhia tinham sido utilizados, durante três dias, numa operação militar que se saldara pela captura de um cunhete de munições e pela destruição de umas quantas palhotas. Ora o país não se podia dar ao luxo de utilizar uma táctica de guerra tão dispendiosa para obter resultados quase nulos ${ }^{42}$.

Segundo a PIDE/DGS, o interesse nacional exigia a imediata substituição do general Kaulza de Arriaga. Caso tal não acontecesse, um dia, quando o governo acordasse, a situação de Moçambique seria desesperada ${ }^{43}$.

Em Setembro de 1972, a PIDE/DGS considerava "grave" a situação militar no distrito de Tete ${ }^{44}$. E assinala que a FRELIMO ia abrir, em breve, duas novas frentes da batalha: uma, nos distritos da Beira e de Vila Pery, cobrindo uma área de 129.854 quilómetros quadrados; a outra no distrito da Zambézia, com uma área de 102.880 quilómetros quadrados. Aliás, pouco depois, há notícia da existência de guerrilheiros na serra da Morrumbala, na Zambézia ${ }^{45}$.

Em princípios de 1973, no Norte do distrito de Cabo Delgado, a FRELIMO continuava a manter as suas posições, ao passo que no Sul a situação se vinha progressivamente a deteriorar. No distrito de Tete, apresentava-se "cada vez mais bem armada e agressiva, dificultando de modo substancial a movimentação das nossas forças. E estas parecem não estar à altura de resolver

${ }^{40}$ IAN/TT, Arquivo da PIDE, Processo SC - CI(2) - DSI, Documentação referente a Moçambique, pasta 7 , fls. $1 / 13$.

${ }^{41}$ IAN/TT, Arquivo da PIDE, Processo SC - CI(2) GU, Pastas de Moçambique, caixa 4, fls. 308 ss.

${ }^{42}$ IAN/TT, Arquivo da PIDE, Processo SC - CI(2) GU, Pastas de Moçambique, caixa 12, fls. $615 / 616$.

${ }^{43}$ IAN/TT, Arquivo da PIDE, Processo SC - CI(2) GU, Pastas de Moçambique, caixa 10 , fls. $426 / 450$.

${ }^{44}$ IAN/TT, Arquivo da PIDE, Processo SC-CI(2) - DSI, Documentos referentes a Moçambique, pasta 3 .

${ }^{45}$ IAN/TT, Arquivo da PIDE, Processo SC - CI(2) - DSI, Documentação referente a Moçambique, pasta 7 , fls. 1/13. 
satisfatoriamente o grave problema que se lhes depara. Pouca disciplina e falta de combatividade parecem ser as brechas mais salientes das nossas forças", refere a PIDE/DGS ${ }^{46}$.

Em Abril de 1973, a polícia anuncia uma visita de Kaulza de Arriaga a alguns quartéis de Tete. Refere que, nessas ocasiões, os responsáveis militares "apressadamente ordenavam que os soldados vestissem os seus camuflados e mandavam-nos para o mato, nos arredores do quartel". Contudo, mal o comandante-chefe se retirava, os soldados recolhiam ao quartel. "Assim, para onde caminhamos?", interroga a $\operatorname{PIDE}^{47}$. De resto, um relatório de situação sublinha que o estado de espírito dos milicianos ia "de mal a pior", sendo estes militares que faziam "a guerra de braços caídos, pois quando vão para o mato não procuram o inimigo e fazem tudo para não o encontrarem "48.

Em Maio desse mesmo ano, a situação geral do distrito de Tete era considerada "simplesmente caótica". Os guerrilheiros da FRELIMO dominavam o mato e controlavam "milhares e milhares de elementos da população", perturbando seriamente as vias terrestres de comunicação ${ }^{49}$.

Em meados de 1973, a FRELIMO começa a atacar cidades e vilas.

Em Cabo Delgado, ataca Mocímboa da Praia com elevados efectivos, calculados em cerca de 600 elementos, incluindo guerrilheiros e carregadores. Usa armamento pesado, designadamente canhões sem recuo, canhões de $73 \mathrm{~mm}$ e morteiros de $82 \mathrm{~mm}$. São atingidas instalações militares, assim como edifícios públicos e privados. A reacção das tropas portuguesa é fraca ${ }^{50}$.

São também atacadas com morteiros e canhões Mueda e Nangade ${ }^{51}$. Num relatório de situação, a subdelegação de Nampula da PIDE/DGS alude aos "crescentes exitos" da FRELIMO, que "os comunicados oficiais em vão pretendem subestimar"

${ }^{46}$ IAN/TT, Arquivo da PIDE, Processo SC - CI(2) GU, Pastas de Moçambique, caixa 15, fls. 507/515 e 526/541.

${ }^{47}$ IAN/TT, Arquivo da PIDE, Processo SC - CI(2) GU, Pastas de Moçambique, caixa 17, fls. $267 / 284$.

${ }^{48}$ IAN/TT, Arquivo da PIDE, Processo SC - CI(2) GU, Pastas de Moçambique, caixa 26, fls. $587 / 605$.

${ }^{49}$ IAN/TT, Arquivo da PIDE, Processo SC - CI(2) GU, Pastas de Moçambique, caixa 17, fls. $32 / 49$.

${ }^{50}$ IAN/TT, Arquivo da PIDE, Processo SC - CI(2) GU, Pastas de Moçambique, caixa 22, fls. $36 / 39$.

${ }^{51}$ IAN/TT, Arquivo da PIDE, Processo SC - CI(2) GU, Pastas de Moçambique, caixa 24, fls. 179 e 400 .

${ }^{52}$ IAN/TT, Arquivo da PIDE, Processo SC - CI(2) GU, Pastas de Moçambique, caixa 22, fls. $199 / 204$. 
Na mesma altura é atacada com foguetões de $122 \mathrm{~mm}$ a cidade de Tete. O inspector Piçarra Sabino comenta que "a continuarmos assim, apáticos ao perigo que nos cerca, não tardará que o inimigo nos metralhe no próprio centro da cidade, tão fraca é a vigilância que exercemos para nossa defesa",53.

É assinalada a presença de Samora Machel, Sebastião Mabote e Joaquim Chissano, no distrito de Tete, acompanhando uma delegação estrangeira ${ }^{54}$. E destaca-se que a subversão alastrava, forçando à dispersão de efectivos. Só que, sublinha a polícia, "desse modo, as possibilidades de êxito das nossas forças diminuem na proporção inversa a este alastramento" "55.

A PIDE alude ao "grande receio" que se apossara dos dirigentes sul-africanos quanto à situação de Moçambique, salientando mesmo que alguns círculos afirmavam "estar a luta perdida, a menos que sejam introduzidas alterações radicais". E a este propósito informa que as tropas rodesianas a operar em Tete iriam ser reforçadas com 600 elementos da polícia sul-africana ${ }^{56}$.

Comentando as acções da FRELIMO nos distritos de Cabo Delgado e, em especial, do Niassa, a polícia escreve: "Eficácia positiva». Tem "quadros dotados de boa preparação técnica", com "excelente material" e "combatentes experientes na táctica da luta de guerrilhas" "57.

Num Relatório Confidencial para a Direcção Geral, referente ao terceiro trimestre de 1973, a Delegação da PIDE/DGS de Moçambique refere que os centros de actividade da FRELIMO se situavam em Cabo Delgado, no Niassa e em Tete, assim como na Beira e Vila Pery, distritos designados como Frente de Manica e Sofala ou $5^{\text {a }}$ Frente. Referindo-se à eficácia das actividades da FRELIMO considera-a "positiva e em elevado grau”, pois dispunha já de quadros dotados de preparação técnica, de excelente material e de combatentes experientes na táctica da luta de guerrilha. Especifica o armamento utilizado, assinalando que todo o equipamento lhe era fornecido pelos "países comunistas", em que se destacam a União Soviética e a China. E passa a assinalar o volume de actividades da FRELIMO, de Julho a Outubro de 1973:

${ }^{53}$ IAN/TT, Arquivo da PIDE, Processo SC - CI(2) GU, Pastas de Moçambique, caixa 23, fls. $292 / 317$.

${ }^{54}$ IAN/TT, Arquivo da PIDE, Processo SC-CI(2) - DSI, Documentos referentes a Moçambique, pasta 15 , fls $22 / 28$.

${ }_{55}$ IAN/TT, Arquivo da PIDE, Processo SC - CI(2) GU, Pastas de Moçambique, caixa 25, fls. $8 / 29$.

${ }^{56}$ IAN/TT, Arquivo da PIDE, Processo SC - CI(2) GU, Pastas de Moçambique, caixa 23, fls. $353 / 354$.

${ }^{57}$ IAN/TT, Arquivo da PIDE, Processo SR 2826/62, FRELIMO, $12^{\circ}$ volume, fls. 2/3. 
Quadro I

Síntese das actividades da FRELIMO (Jul./Agosto 1973)

\begin{tabular}{|c|c|c|c|c|c|}
\hline & Cabo Delgado & Niassa & Tete & Manica e Sofala & TOTAL \\
\hline Operações & 434 & 125 & 826 & 156 & 1.541 \\
\hline Mortos & $46(18)$ & $25(16)$ & $120(41)$ & $28(12)$ & $219(87)$ \\
\hline Feridos & $311(150)$ & $77(33)$ & $269(157)$ & $87(60)$ & $744(400)$ \\
\hline Raptados & 133 & 91 & & & 224 \\
\hline
\end{tabular}

Fonte: IAN/TT, Arquivos da PIDE, processo $332 \mathrm{CI}(2)$, Armamento, pasta 3, fls. 65 ss. Nos mortos e feridos, entre parêntesis, assinalam-se os militares.

Depois de salientar terem existido rivalidades tribais que criaram sérias dificuldades à FRELIMO, o relatório sublinha que, naquela altura, graças ao esforço dos independentistas, aquelas rivalidades já não tinham expressão significativa. Acrescenta não ter viabilidade, no curto prazo, a hipótese de conflitos militares no seio da FRELIMO. Afirma ainda que, naquele momento, a orientação dos dirigentes era pró-Moscovo, embora se registasse entendimento com a China. E destaca não se conhecerem divergências ideológicas no seio dos principais dirigentes da FRELIMO, que aceitariam ajudas "seja de quem for, para o desenvolvimento da luta".

A propaganda da FRELIMO, orientada pelo Departamento de Informação e Propaganda, ter-se-ia aperfeiçoado extraordinariamente nos últimos anos, orientando-se para as etnias-chave. A FRELIMO dedicaria um cuidado muito especial à exploração dos aspectos negativos da Administração colonial e da actuação das autoridades. "A receptividade por parte da população é grande, mesmo em zonas onde não existem acções violentas, pelo facto de as motivações apresentadas irem ao encontro das aspirações dos africanos", afirma o relatório da polícia, destacando: "Nós, para conquistarmos a população, temos de prometer e cumprir. Ao inimigo basta prometer" 58 .

E num Relatório Extraordinário de finais de 1973 sublinha-se:

"A situação em Cabo Delgado tem-se agravado progressivamente nos últimos meses", podendo a FRELIMO "intensificar a sua acção em todos os campos e em todas as regiões do distrito", onde existiriam cerca de quatro mil guerrilheiros equipados com armamento moderno. Utilizavam, pois, o seu "grande poderio bélico e pessoal contra mal defendidos objectivos".

\footnotetext{
${ }^{58}$ IAN/TT, Arquivos da PIDE, Processo 332 - CI(2), Armamento, pasta 3, fls. 65/74.
} 
No Niassa, a situação sofrera alteração, em consequência do "ligeiro aumento de actividade da FRELIMO”. A infiltração na parte oriental do distrito de cerca de uma centena de guerrilheiros com morteiros e outro material devia alterar a situação em favor dos independentistas.

No distrito de Tete, a situação apresentava "um elevado índice de deterioração". A FRELIMO continuava "agressiva e a deambular atrevidamente em redor da cidade de Tete”, avançando para Manica e Sofala.

E no distrito de Vila Pery, a situação continuava a deteriorar-se, ameaçando estender-se para zonas mais a sul ${ }^{59}$.

Em princípios de 1974, verifica-se uma acção de sabotagem na linha férrea Beira-Machipande e o ataque a uma coluna militar na estrada Beira-Untali. Além disso, um grupo de três guerrilheiros da FRELIMO, armados de Kalashnikov, é visto por duas vezes na cidade da Beira, movimentando-se com perfeito à vontade num minucioso reconhecimento de objectivos. A situação nos distritos de Tete e da Beira, particularmente na estrada que conduz à Rodésia, era considerada "gravíssima" e sem perspectivas de melhoria ${ }^{60}$.

Os guerrilheiros manifestam-se particularmente activos na região de Inhaminga, a uma escassa centena de quilómetros da cidade da Beira. Segundo a polícia, a deterioração da situação político-militar teria colocado a população europeia "em manifesto desequilíbrio psicológico", mostrando-se "muito preocupada e insegura" e não acreditando já na eficácia das tropas portuguesas ${ }^{61}$. De resto, nalgumas localidades, grupos de europeus armados apareciam a fazer rondas nocturnas ${ }^{62}$.

$\mathrm{Na}$ cidade da Beira, centenas de colonos portugueses tinham-se manifestado contra os militares, por mais de uma vez. Os manifestantes acabam por ser dispersos à bastonada ${ }^{63}$. O inspector superior São José Lopes, responsável pela PIDE/DGS nas colónias, num relatório sobre as causas dos incidentes, assinala: primeira, a "divisão entre civis e militares", agravada com o avanço da subversão para sul, "ameaçando seriamente os distritos da Beira e de

${ }^{59}$ IAN/TT, Arquivo da PIDE, Processo SC - CI(2) GU, Pastas de Moçambique, caixa 26, fls. $339 / 362$.

${ }^{60}$ IAN/TT, Arquivo da PIDE, Processo SC - CI(2) GU, Pastas de Moçambique, caixa 29, fls. $15 / 17$ e 119 ss.

${ }^{61}$ IAN/TT, Arquivo da PIDE, Processo SC-CI(2) - DSI, Documentos referentes a Moçambique, pasta 13 , fls. $48 / 49$.

${ }^{62}$ IAN/TT, Arquivo da PIDE, Processo SC-CI(2) - DSI, Documentos referentes a Moçambique, pasta 13,f.160.

${ }^{63}$ IAN/TT, Arquivo da PIDE, Processo SC-CI(2) GU, Pastas de Moçambique, caixa 30, fls. $114 / 127$. 
Vila Pery e, em especial, toda a área ao longo das vias rodo e ferroviária Beira/Untali"; segunda, a incompreensível falta de preparação psicológica da população europeia, a quem não tinham sido proporcionados meios de defesa; terceira, a "tibieza do governo do distrito", com pouca ou nenhuma aceitação; quarta, a má actuação da PSP; quinta e última, a indisciplina dos europeus. O inspector superior do Ultramar afirma ter informado com antecedência e com toda a objectividade do que se viria a passar num curto prazo. Contudo, ninguém fizera caso das suas advertências, porventura porque "alguém muito responsável afirmara que a guerra, militarmente, estava ganha”, clara alusão ao general Kaulza de Arriaga. E o responsável da PIDE/DGS terminava dizendo que aquela afirmação, que visava determinados fins, menosprezava as consequências de ordem psicológica que viria a ter na população europeia ${ }^{64}$.

Mas os problemas dos colonos não se resumiam à insegurança. De facto, no Norte de Moçambique, verificava-se uma "escalada vertiginosa do custo de vida" a a "progressiva escassez de produtos alimentares de uso corrente". Surgiam bichas e disputas por um simples quilo de batatas. E havia mesmo quem aparecesse a sugerir a reintrodução das "senhas de racionamento" já existentes durante a Segunda Guerra Mundial ${ }^{65}$.

Em Fevereiro de 1974, os relatórios de situação assinalam que, no Niassa, a "agressiva" FRELIMO desenvolvia uma "actividade significativa" e, em Cabo Delgado, com "grande agressividade", promovia emboscadas, flagelações e ataques a quartéis ${ }^{66}$. No centro, a FRELIMO fixara-se nas áreas de Inhaminga e da Gorongosa. A fixação na Gorongosa e a extensão das acções para Leste permitia-lhe alcançar vários objectivos, designadamente cortar Moçambique ao meio e levar a subversão armada até à Zambézia, onde o panorama político era preocupante ${ }^{67}$.

De modo que, com base nas informações disponíveis, o próprio Marcelo Caetano afirmava que "em Cabo Delgado se mantinha a pressão do inimigo, apoiado na Tanzânia", que "no distrito de Tete a subversão progredia a olhos vistos" e que se estava na "iminência da chegada dos guerrilheiros ao planalto

${ }^{64}$ IAN/TT, Arquivo da PIDE, Processo SC-CI(2) GU, Pastas de Moçambique, caixa 30, fls. $285 / 289$.

${ }^{65}$ IAN/TT, Arquivo da PIDE, Processo SC-CI(2) GU, Pastas de Moçambique, caixa 31, fls. $174 / 182$.

${ }^{66}$ IAN/TT, Arquivo da PIDE, Processo SC-CI(2) GU, Pastas de Moçambique, caixa 31, fls. $110 \mathrm{ss}$.

${ }^{67}$ IAN/TT, Arquivo da PIDE, Processo SC-CI(2) GU, Pastas de Moçambique, caixa 32, fls. 552 ss. 
de Manica, a Vila Pery e à própria cidade da Beira" ${ }^{68}$. Antevendo mesmo o colapso militar ${ }^{69}$.

Chegam, entretanto, os mísseis Strella. Confirma-se ter sido abatido um avião rodesiano $^{70}$. E a FRELIMO prepara-se para ampliar a sua acção na Zambézia.

\section{A guerra na Guiné}

$\mathrm{Na}$ Guiné, a luta armada de libertação nacional inicia-se, em 23 de Janeiro de 1963, com o ataque, por uma centena de guerrilheiros, ao quartel de Tite, na margem esquerda do rio Geba, onde estava instalado o comando de um batalhão português. Em Julho desse mesmo ano, a guerra atinge aos florestas do Oio, a norte do Geba. De modo que, em finais de Agosto de 1963 e como o sublinha um militar português, "a situação na enorme região que abrange Bissorã, Bissar, Encheia, Mansoa, Mansabá e Olossato, não era muito diferente da existente em grande parte do sul da província: populações fugidas, tabancas abandonadas ou destrídas, estradas obstruídas, a vida administrativa e a actividade comercial profundamente afectadas" $"$.

Em Fevereiro de 1963, sob o comando de Malan Sanha, os guerrilheiros prendem o capitão Carreira Curto, acusado de ter executado sumariamente centenas de africanos. Na mesma altura, outro grupo de guerrilheiros faz uma emboscada em Fulacunda, tendo prendido dez soldados, um dos quais seria depois libertado ${ }^{72}$. E em fins desse ano, o Comandante Militar, brigadeiro Louro de Sousa, desloca-se a Lisboa para expor ao Conselho Superior Militar a "situação gravíssima” que a colónia atravessa.

Como resposta, em Janeiro de 1964, as tropas portuguesas realizam uma acção de grande envergadura, com o nome de código de "Operação Tridente", com o objectivo de desalojar os guerrilheiros do PAIGC da ilha de Como. A operação, que se prolonga por várias semanas, acaba por ter resultados desastrosos para as forças coloniais. Hélio Felgas, oficial português que é um destacado teórico da chamada "guerra subversiva", referindo-se à actividade armada, destaca que, nos finais do primeiro semestre de 1964, os grupos de guerrilheiros do PAIGC actuavam em praticamente todo o sul abaixo do Geba e a oeste do Corubal (com excepção da ilha de Bolama e da área da Aldeia

\footnotetext{
${ }^{68}$ Marcelo Caetano, Depoimento, Intervenção, Lisboa, 1976, p. 191.

${ }^{69}$ Jorge Jardim, Moçambique, Terra Queimada, p. 117.

${ }^{70}$ IAN/TT, Arquivo da PIDE, Processo SC-CI(2) GU, Pastas de Moçambique, caixa 34, f. 39.

${ }^{71}$ Hélio Felgas, Guerra na Guiné, SPEME, Lisboa, 1967, p. 69.

${ }^{72}$ IAN/TT, Arquivo da PIDE, Processo 641/61, PAIGC, pasta 1, f. 271.
} 
Formosa), assim como na região entre os meridianos de Bula e Bafatá (com exclusão das áreas de Bissau e Nhacra - Mansoa) ${ }^{73}$.

Confrontado com o agravamento da situação, o Governo português substitui os comandos militares e políticos. Em Maio de 1964, é designado Governador e simultaneamente Comandante-chefe o brigadeiro Arnaldo Shultz.

\section{GUINÉ BISSAU}

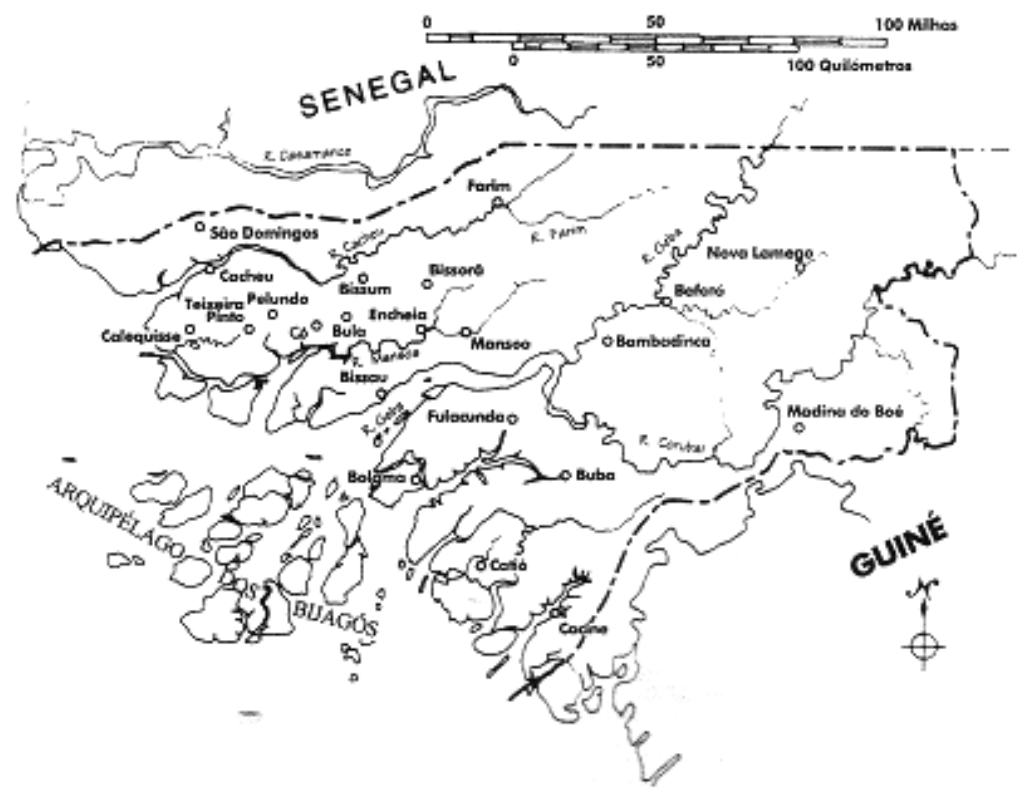

Em Junho de 1965, um grupo de guerrilheiros teria entrado na Guiné, a Norte de Buruntuma, supondo-se que se deslocassem para as áreas de Amora e Sare Buré. Na mesma altura teriam entrado na Guiné, pela região de S. Domingos e Inguré, 200 guerrilheiros. A presença deste mesmo grupo é assinalada naquela área nos princípios de Agosto. Além disso, um contingente do PAIGC saíra de Kindir para Koundara. Em Agosto, um grupo de 92 guerrilheiros, dos quais 15 estavam feridos, passou em direcção a Farim ${ }^{74}$.

\footnotetext{
${ }^{73}$ Hélio Felgas, Op. Cit., pp 89/91.

${ }^{74}$ IAN/TT, Arquivo da PIDE, Processo 641/61, PAIGC, pasta 1, fls. 60 ss.
} 
Na segunda quinzena de Dezembro de 1966, a PIDE refere infiltrações e acções dos guerrilheiros, uma reunião de dirigentes políticos e militares e preparativos para uma ofensiva, em Dezembro 66 ou Janeiro de 1967, atribuídas ao esforço para manter a unidade ${ }^{75}$.

Facto é que, em 1967, as forças portuguesas tinham perdido o controlo do sul e do centro-sul. E tendo fracassado as tentativas de penetração nas chamadas áreas libertadas, tinham-se abandonado as grandes operações, "deixando aos guerrilheiros vastas áreas por onde eles se movimentavam em completa segurança" "76.

Em Maio de 1968, Shultz é substituído pelo general Spínola, que vai alterar significativamente a estratégia. Começa por despedir altos comandos militares e civis, remodelando o dispositivo. E adopta uma manobra diferente para cada área: nuns lados, "o esforço de penetração nas zonas fronteiriças", noutros, "a defesa das populações", ainda noutros, "a acção psicológica”. E nas áreas inimigas, a "atitude defensiva" ou a "contra-guerrilha".

Em princípios de 1970, a PIDE assinala que o "potencial presente" do PAIGC lhe permitia, "a qualquer momento, acelerar o processo evolutivo da guerra" "77, destacando, ainda, que já tinham começado a entrar viaturas no território da colónia com "material cada vez em maior quantidade 78 ".

Ainda em 1970, a PIDE/DGS toma conhecimento das acções de aliciamento realizadas por três majores portugueses junto de elementos do PAIGC. E descobre, ainda, que a um desses contactos, realizado na estrada de Teixeira Pinto para Cacheu, se deslocara pessoalmente o general António de Spinola, que, entretanto, nunca dera qualquer informação à polícia sobre o que se passava. O responsável da Delegação faz saber ao general que "muita gente de Bula" estava a par do assunto, "pelo que o segredo de tais conversações não existia”. E segundo informações recolhidas posteriormente pela polícia, as movimentações no "chão manjaco" até já tinham chegado ao conhecimento de Amilcar Cabral. Ao que parece, as advertências da polícia não foram levadas em conta. E os majores foram mortos ${ }^{79}$.

${ }^{75}$ IAN/TT, Arquivo da PIDE, Processo 110.00.30, MPLA, pasta 7, fls 62/63.

${ }^{76}$ Carlos Fabião, «A Descolonização da Guiné-Bissau», in AA.VV., Seminário 25 de Abril - Dez Anos Depois, Associação 25 de Abril, Lisboa, 1984, p. 305.

${ }^{77}$ IAN/TT, Arquivo da PIDE, SC, Pastas Organizadas por Províncias Ultramarinas - Guiné, caixa 2 , fls $1 / 45$.

${ }^{78}$ IAN/TT, Arquivo da PIDE, SC, Pastas Organizadas por Províncias Ultramarinas - Guiné, caixa 4 , fls 313/315.

${ }^{79}$ IAN/TT, Arquivo da PIDE, SC, Pastas por Províncias Ultramarinas, Guiné, caixa 10, fls. $100 / 101$. 
Em 1971, Bissau é atacada com foguetões. E Nova Lamego é, também, atacada com armas pesadas, durante 40 minutos $^{80}$.

No início de 1972, em Bissau, durante três dias seguidos, rebentam bombas, uma delas junto à porta principal do edifício da PIDE/DGS ${ }^{81}$. Na mesma altura, a polícia detecta a presença de Nino Vieira nos acampamentos de Timbó e Incala, da área de Bedanda, assim como de Cachabar, da área de Cubisseco, de onde seguiu para Quinane. Refere, ainda, que o PAIGC impedia a deslocação das populações aos centros comerciais das localidades controladas pelas autoridades portuguesas, para evitar a fuga de informações ${ }^{82}$. Em Fevereiro, teria havido ordem de Nino Vieira para que Bolana fosse atacada ${ }^{83}$. E em meados do ano, Nino Vieira teria estado em Morés, a planear o ataque às povoações de Braia e Infandre, na área de Mansoa. Dali seguiria para Sara e para Canjambari, propondo-se atacar Mansoa, Cussana, Jugudul, Nhacra e, depois, Farim ${ }^{84}$. Ataques vários na área de Mansoa, causam mortos e feridos ${ }^{85}$. É, também, atacada a vila de Catió e, ainda, bombardeada uma base aérea ${ }^{86}$.

Em fins de 1972, numa mensagem de rádio para a Direcção Geral, os responsáveis da Delegação afirmam que o PAIGC recebera recentemente "muito material de guerra, nomeadamente novo tipo de foguetões, viaturas blindadas e armas antiaéreas", tendo também entrado no país centenas de guerrilheiros, "muitos deles recém-chegados da União Soviética”. Destaca-se, ainda, que "as bases tradicionais de Morés, Sara e Coquemane" tinham recebido "consideráveis reforços de pessoal e material ligeiro, aguardando material pesado constituido por novo tipo de foguetões". E a mensagem conclui afirmando que "infelizmente somos forçados a admitir que Cabral terá possibilidades de realizar os seus objectivos..." "87.

Em princípios de 1973, antecipando a saída do general Spinola da Guiné, Fragoso Allas, num relatório enviado à Direcção Geral, assinala que a "tão discutida política de africanização" e de "diálogo com o povo" desagradara aos europeus e enganara a maioria esmagadora dos africanos, embora "a camada

${ }^{80}$ IAN/TT, Arquivo da PIDE, SC, Pastas por Províncias Ultramarinas, Guiné, caixa 8, fls. 227 e 364.

${ }^{81}$ IAN/TT, Arquivo da PIDE, SC, Pastas por Províncias Ultramarinas, Guiné, caixa 12, fls. $673 / 675$.

${ }^{82}$ IAN/TT, Arquivo da PIDE, Processo 641/61, PAIGC, pasta 3, fls 78 ss.

${ }^{83}$ IAN/TT, Arquivo da PIDE, Processo 641/61, PAIGC, pasta 3, fls 48/51.

${ }^{84}$ IAN/TT, Arquivo da PIDE, Processo 641/61, pasta 4, fls. 205/211.

${ }^{85}$ IAN/TT, Arquivo da PIDE, Processo 641/61, pasta 4, fls. 581/582.

${ }^{86}$ IAN/TT, Arquivo da PIDE, SC, Pastas por Províncias Ultramarinas, Guiné, caixa 12, fls. 310

${ }^{87}$ IAN/TT, Arquivo da PIDE, SC, Pastas por Províncias Ultramarinas, Guiné, caixa 14, f. 450. 
mais evoluida dos africanos de Bissau” se tivesse apercebido de que, no fundo, tal política eram "mais palavras do que actos"

Em Maio de 1973, são atacados os quartéis de Guidege e de Bigene, junto à fronteira com o Senegal. E nessa área são abatidos dois aviões, tendo morrido os pilotos ${ }^{89}$. A polícia refere que "a utilização desta nova arma [míssil terra-ar] constitui um sério agravamento da situação, porque nos tira o domínio do espaço aéreo". E destaca ainda que, antes, "só o apoio aéreo foi decisivo para evitar desaires" " Segundo a polícia, o PAIGC tinha uma nova táctica. Flagelava destacamentos do exército português, alvejando depois os meios aéreos que acorriam aos pedidos de apoio de fogo ${ }^{91}$.

O quartel de Guilege, na fronteira com a Guiné, é, também, atacado, em Maio de 1973. Os militares abandonam-no e recolhem a Gadamael. O comandante acaba sendo preso e considera-se que o abandono de Guilege se devia à "falta de determinação das tropas" recentemente chegadas da Metrópole ${ }^{92}$. Em princípios de Junho é o quartel de Gadameal a ser atacado pelo PAIGC. $\mathrm{O}$ ataque provoca oito mortos e um número indeterminado de feridos, entre os quais dois capitães e o médico. Dado o estado de espírito dos militares, que não se alimentavam nem dormiam, o comandante pede para evacuar o quartel. Recebe ordens para aguentar a posição "a todo o custo". Contudo, ao abrigo da noite, cerca de 40 militares fogem de Gadameal em dois botes, dirigindo-se a Cacine. Aqui, o Comandante-Chefe obriga-os a regressar a Gadamael, sob a ameaça de que "quem recusasse seria imediatamente fuzilado". A PIDE/DGS sublinha que, "além da evidente falta de meios", havia "uma nitida falta de determinação das tropas europeias, incluindo oficiais permanentes" 93.

$\mathrm{O}$ inspector adjunto Fragoso Allas, em carta enviada nessa altura para a Direcção Geral, escreve: “(...) Praticamente perdemos a vantagem da Força Aérea e não dispomos de meios aéreos que possam constituir força de dissuasão ou que nos permitam castigar duramente as bases de apoio. Temos que encarar como possivel que o PAIGC venha, em curto prazo de tempo, a estabelecer

${ }^{88}$ IAN/TT, Arquivo da PIDE, SC, Pastas por Províncias Ultramarinas, Guiné, caixa 14, fls. $114 / 115$.

${ }^{89}$ IAN/TT, Arquivo da PIDE, SC, Pastas por Províncias Ultramarinas, Guiné, caixa 15, fls. $509 / 510$ e 692 .

${ }^{90}$ IAN/TT, Arquivo da PIDE, Processo 641/61, PAIGC, pasta 7, fls. 229/230.

${ }^{91}$ IAN/TT, Arquivo da PIDE, Processo 641/61, PAIGC, pasta 7, fl. 132.

${ }^{92}$ IAN/TT, Arquivo da PIDE, SC, Pastas por Províncias Ultramarinas, Guiné, caixa 15, f. 505 .

${ }^{93}$ IAN/TT, Arquivo da PIDE, SC, Pastas por Províncias Ultramarinas, Guiné, caixa 15, fls. $425,447 / 448$ e 450 . 
'novas áreas libertadas'e a dificultar ou impedir o tráfego aéreo e até mesmo a aniquilar algumas guarnições que agora passam a não poder contar com o apoio aéreo para as defender, evacuar os feridos ou reabastecer". E mais adiante acrescentava: "Consideramos muito grave a situação resultante do emprego pelo PAIGC de novas armas antiaéreas, tanto mais que toda a gente crê saber que não dispomos de meios aéreos em quantidade e capacidade para uma operação eficaz" ${ }^{94}$.

Em relação às aeronaves da Base Aérea $\mathrm{n}^{\circ} 12$, a polícia assinala, também, várias acções de sabotagem: nos helicópteros apareciam porcas desapertadas e o cabo eléctrico dos canhões desligado; e nos aviões surgiam avarias e, ainda, defeitos nas bombas de 750 libras ${ }^{95}$.

Por essa mesma altura, o inspector José Galante, chefe do posto de Leiria da PIDE/DGS, envia a Álvaro Pereira de Carvalho uma informação sobre a situação militar. Diz ter obtido, de "fonte fidedigna", a notícia de que António de Spínola se preparava para deixar brevemente a Guiné, território que se encontrava numa situação crítica, face à "crescente concentração de material de guerra na fronteira do Senegal”. Na informação que dera a um amigo seu, o general afirmava que "a situação era de tal gravidade que esperava se desse um colapso", tendo advertido o Governo para tal hipótese. E prevendo a impossibilidade de resistir ao poderio militar do PAIGC, o general "teria tentado entabular negociações com o grupo de Amilcar Cabral" 96 .

Esta informação sobre a situação militar está hoje perfeitamente confirmada. Com efeito, em Maio de 1973, em plena crise de Guidege, o general Spinola informa o titular da Defesa, Silva Cunha, de que "nos aproximamos, cada vez mais, da contingência do colapso militar”. E teria, ainda, sublinhado, que a solução do problema não era militar, porque "de há uns tempos para cá, o PAIGC alcançou uma inesperada supremacia em potencial de guerra" ${ }^{97}$.

Em Setembro de 1973, os guerrilheiros atacam uma coluna das tropas portuguesas, no itinerário que leva de Teixeira Pinto a Bissau. E a PIDE/DGS considera que a inércia das tropas portuguesas é "praticamente total"98.

${ }^{94}$ IAN/TT, Arquivo da PIDE, Processo 641/61, PAIGC, pasta 7, fls. 190/192.

${ }^{95}$ IAN/TT, Arquivo da PIDE, SC, Pastas por Províncias Ultramarinas, Guiné, caixa 16, fls. $592 / 594$.

${ }^{96}$ IAN/TT, Arquivo da PIDE, SC, Pastas por Províncias Ultramarinas, Guiné, caixa 15, fls. $456 / 457$.

${ }^{97}$ Nuno Mira Vaz, Guiné..., pp. 54/55.

${ }^{98}$ IAN/TT, Arquivo da PIDE, Processo 641/61, PAIGC, pasta 9, fls 306 ss. 
Em Janeiro de 1974, rebentam em Bissau engenhos explosivos, designadamente à entrada da Base Aérea ${ }^{\circ} 12$, em frente à messe de sargentos da Força Aérea e na viatura de uma funcionária da PIDE/DGS, que fica destruída. No mês seguinte, rebenta nova bomba, desta vês no Quartel General, rebentamento de que resultam ferimentos num brigadeiro e num coronel ${ }^{99}$. Em Lisboa, o jornal República notícia que "rebentou uma bomba no Quartel General de Bissau”" Na sequência dos rebentamentos, a polícia prende Rafael Barbosa, que não nega a sua ligação aos elementos que tinham implantado os engenhos explosivos, embora se recuse a identificá-los ${ }^{101}$.

Na mesma altura, os militares portugueses, por decisão superior, abandonam Copá, recolhendo a Bajocunda. O aquartelamento abandonado, depois do ataque do PAIGC, ficara muito danificado e com grandes dificuldades de abastecimento, pois fora minada a estrada que a ele conduzia. É, entretanto, abatido com um míssil "Strella" mais um avião FIAT ${ }^{102}$. É uma "arma antiaérea formidável", "altamente eficaz", comenta a PIDE/DGS ${ }^{103}$.

Marcelo Caetano defende para a Guiné uma "derrota militar com honra"104.

\section{Conclusões}

Os relatórios da PIDE/DGS, de que aqui apresentámos um lote significativo de exemplos, fornecem, segundo cremos, um quadro expressivo da situação militar nas colónias em guerra. Esta situação foi, quanto a nós, magistralmente resumida pelo falecido marechal Costa Gomes, quando declarou: "As informações de que então dispúnhamos diziam claramente que, em Moçambique, a guerra piorava de dia para dia e que, na Guiné, se estava à beira do colapso. Só em Angola, então, se vivia um sossego pelo menos aparente". No entanto, reconhecia tratar-se de "uma situação transitória" 105. E assim, mesmo em Angola, o "sossego era aparente" e a "situação transitória".

${ }^{99}$ IAN/TT, Arquivo da PIDE, SC, Pastas por Províncias Ultramarinas, Guiné, caixa 16, fls. 83 e 1199/200.

${ }^{100}$ República, 23.02.1974.

${ }^{101}$ IAN/TT, Arquivo da PIDE, SC, Pastas por Províncias Ultramarinas, Guiné, caixa 16, fls. $78 / 79$.

${ }^{102}$ IAN/TT, Arquivo da PIDE, SC, Pastas por Províncias Ultramarinas, Guiné, caixa 16, fls. 83 e 199/200.

${ }^{103}$ IAN/TT, Arquivo da PIDE, Processo 332 CI (2), Misseis, pasta 5, folha 15.

${ }^{104}$ Marcelo Caetano, Depoimento, Distribuidora Record, Rio de Janeiro, 1974, p. 191.

${ }^{105}$ Maria Manuela Cruzeiro, Costa Gomes, o Último Marechal, Notícias, Lisboa, 1998, pp. 199 e 165. 
Na Guiné e em Moçambique, o moral das tropas portuguesas era bastante baixo. Tal facto estaria ligado à própria situação militar. Com efeito, na Guiné, a luta de guerrilhas entrara na sua quinta e última fase, a da insurreição geral, com métodos de guerra próprios das forças convencionais e com a vitória próxima $^{106}$. Ao passo que, em Moçambique, o combate se encontrava em fase muito adiantada, o que levava o próprio Marcelo Caetano, interpretando claros sinais da PIDE/DGS, a admitir, também, um colapso militar. E se, em Angola, as divisões internas e a luta entre os movimentos, tudo conjugado com alguma habilidade político-militar por parte das forças portuguesas, eram factor de atraso e de dificuldades na luta de libertação nacional, a situação podia inverter-se a qualquer momento, graças a condições africanas e internacionais facilitadoras e ao estado de espírito de largas camadas de angolanos.

Nos diversos campos de batalha, os soldados portugueses não manifestavam disposição para continuar a combater. Em Agosto de 1973, em conversa com Diogo Freitas do Amaral, Marcelo Caetano afirmava que "as Forças Armadas, que existem para fazer a guerra, já não se querem continuar a bater, e o que desejam é fazer a paz", acrescentando que o moral das tropas era péssimo e que não sabia dizer por quanto tempo mais aguentariam o grande esforço que lhes era pedido, embora suspeitasse que não fosse por muito ${ }^{107}$.

A situação militar e o moral das tropas portuguesas estão na base do 25 de Abril. E ajudam a compreender as dificuldades e atribulações que envolveram todo o processo de descolonização.

${ }^{106}$ Segundo os teóricos, a chamada «Guerra Subversiva» comportaria 5 fases: a primeira, preparatória, decorre em segredo, pelo menos de início; a segunda, de agitação, procura criar o ambiente propício à luta, com propaganda e actos de desobediência civil, que não raro provocam a repressão; na terceira, de subversão violenta, surgem grupos de guerrilheiros armados e organizados, o que leva à intervenção das forças armadas; na quarta, os guerrilheiros criam bases no interior do território e constituem-se em forças quase regulares, cada vez melhor armadas; na quinta, a da insurreição geral, os guerrilheiros começam a utilizar métodos de guerra próprios das forças convencionais.

${ }^{107}$ Freitas do Amaral, O Antigo Regime e a Revolução, Bertrand, VendaNova, 1995, p. 128. 